\title{
Ecology of Polylepis spp Forests, and Proposal for Its Conservation in the Andean Region of Tacna, Peru
}

\author{
Luis Fortunato Morales-Aranibar \\ Universidad Nacional Intercultural de \\ Quillabamba \\ Quillabamba, Perú \\ luis.morales@uniq.edu.pe
}

\author{
Edward Enrique Rojas de la Puente \\ Universidad Nacional Toribio Rodríguez \\ de Mendoza. \\ Amazonas, Perú. \\ edwaro91@hotmail.com
}

\author{
Juan F. Costa \\ Universidad Nacional de San Antonio \\ Abad del Cusco. \\ Cusco, Perú \\ jfrancosta@gmail.com
}

\begin{abstract}
The forests of Polylepis (queñoales) is one of the most important Andean forest ecosystems and with the greatest impact due to human activities. The objectives of the study were to determine the distribution and diversity of queñoa forests in the Andean region of Tacna, Peru. With this information, We propose the restoration and conservation plan for the Polylepis spp. For this purpose plots of $500 \mathrm{~m} 2$ were established. The sampling was simple random, taking a population census in each of the sample units in the 4 provinces (Jorge Basadre, Tacna, Tarata and Candarave). The total evaluation area was 27,491 hectares.
\end{abstract}

The presence of two Polylepis species was identified. Polylepis rugulosa Bitter was registered in 9 districts with an altitudinal range of 3050 to 4226 m.a.s.l. in 6 life zones. Polylepis tarapacana $P$ hil is distributed in the provinces of Tarata and Tacna within 3 districts. $P$. tarapacana occurs in an altitudinal range between 4230 and 4750 m.a.s.l. in 5 life zones. The tall and diameter of tree were variable for two species. The human impact for $P$. rugulosa was recorded: Not Intervented $(\mathbf{7 6 \%} \%$ ), Semi Intervening $(21 \%)$ and Intervened (3\%). For P. tarapacana it was: Not Intervented (77\%), Semi Interventions (21\%) and Intervened (2\%). According to the data gathered, the conservation plan is proposed, consisting of 5 guidelines: 1) education, 2) communication and capacity building, 3) conservation and sustainable management, 4) policies and regulations, and 5) research and monitoring.

Keywords-Ecology, high Andean forests, queñoa, southern of Perú.

\section{INTRODUCTION}

The forests of Polylepis present a great scenic beauty and landscapes, species of flora and fauna specialist of these forests make them unique ecosystems in the world [1]. The distribution of Polylepis species is eminently South American and its distribution is restricted to mountainous areas in the Andes [2]. In [3] argue that the center of diversification would be located in the southern area of the Andes and the greatest diversity of species (18 species) is distributed between 3000 and 4000 meters above sea level. These forests are strongly impacted by human activities, with fire and erosion being the main factors [2].
According to [2], the number of species of the genus Polylepis is 26, of them, 14 species are distributed in Peru and reports three endemic species. In [4] report four endemic species for Peru. Later, [5] concluded the existence of 19 native species for the genus Polylepis, increasing to five the number of endemic species for Peru. Peru has the highest number of queñoa species (19 species) followed by Bolivia with 13 species [3].

The Andean region has particular environmental characteristics such as precipitation, temperature, altitude, among other factors that have influenced the development of a plant community adapted to these conditions, found in it species of great value are these forest, shrub and herbaceous; likewise, it is a promising area of resources, mainly water resources [6]. The surrounding populations make use of these resources indiscriminately due to the increase of the population which demands a greater consumption of this resource, forest products and the expansion of the agricultural frontier. The importance of conserving queñoa forests is increasingly visible. In [7] mention that these forests are vital for biodiversity and hydrological functions taking into account the current increase in anthropogenic pressure that they are suffering, causing fragmentation, deforestation and loss of biodiversity. The objective of the study was to evaluate the current state of the Polylepis forests (queñoas), and we proposed the following specific objectives: 1) determine the area of queñoa forests, 2) determine the density and population structure; and, 3) to determine the affectation of the forests by the anthropic influence, and 4) to propose a plan of conservation of the forests of queñoas in the Tacna region.

\section{MATERIAL AND METHODS}

\section{Study area}

The department of Tacna contains four provinces. The forests of Polylepis are distributed at an altitude between 3400 and 5000 m.a.s.1. The study area includes part of the four provinces of the Tacna region, such as: 
a) Jorge Basadre includes the districts of Locumba, Ilabaya and Ite. The evaluation was carried out in the farming communities of Santa Cruz, which is located in the district of Ilabaya.

b) Candarave is divided into six districts: Candarave, Cairani, Camilaca, Curibaya, Huanuara and Quilahuani. The evaluation was carried out in Camilaca (Quebrada Pantara) and Candarave (skirts of the Yucamani Volcano, Hiltajavira and Colpapampa).

c) Tarata has altitudinal levels that fluctuate between 4200 and $5000 \mathrm{msnm}$ and the assessment areas were located in the districts of Susapaya, Estique Pueblo, Tarucachi, Sitajara, Ticaco and Tarata.

d) Tacna has an area of $16076 \mathrm{~km}^{2}$. The altitudinal extremes are the Tutupaca volcano, 5815 m.a.s.l., the snow-capped mountains of Chupiquiña, 5788 m.a.s.l. and Barroso, $5742 \mathrm{~m}$.as.l. The place of study is located in the high Andean area of the district of Palca, in the province of Tacna, ranging from 4200 to over 5000 m.a.s.l. A cold climate predominates in the mountain range, intense cold and in some cases snowed.

Procedure

Form and delimitation of the plots

The method of sampling by parcels was used, establishing a plot of $20 \mathrm{~m} \times 25 \mathrm{~m}(0.05$ ha) for each zone. Each plot was located randomly throughout the forest and delimited with the help of stakes, raffia and compass [8].

\section{Collection and identification of samples}

Conventional techniques were used for the treatment of botanical samples [9] - [10]. The botanical samples were identified in the Herbarium Vargas (CUZ) of the National University of San Antonio Abad of Cusco.

\section{Density and population structure}

We proceeded to count all the individuals within each plot with the help of a Garmin GPS [8]. The counting of adult individuals, saplings and latizales was carried out; For this, a metal metric tape was used: a) brinzales, from 0 to $30 \mathrm{~cm}, \mathrm{~b}$ ) latizales, $>30 \mathrm{~cm}$ up to $1 \mathrm{~m}$, and c) adults, $>1 \mathrm{~m}$.

\section{Diameter and height of the tree}

The DAP (diameter at breast height) was measured at $1.5 \mathrm{~m}$ towards the slope and the side closest to the ground, with the help of a tape measure [11].

To obtain the total height of the trees; the direct estimation was made, it was measured from the soil to the top of its crown or crown with the help of a metallic tape [11].

\section{Anthropogenic factors}

The guide provided by the Regional Government of Tacna [12] was used: a) Not intervened (good physical condition, vigorous leaves and no anthropic impact), b)
Semi-intervened (slightly damaged, there are few dry leaves), and c) Intervened (broken, cut, dried, burned and dead trees).

\section{RESULTS AND DISCUSSION}

The presence of $P$. tarapacana in Tacna is not more controversial. On the other hand, the presence of $P$. rugulosa is debated. In [13], it is explained that the distribution of $P$. rugulosa includes southern Peru and northern Chile as opposed to P. subtusalbida (Bitter) where its distribution is recorded in Cochabamba and Potosí in Bolivia, in studies of [5] and [7], in the distribution of P. subtusalbida (Bitter) indicate that this species is found in Tacna and in southern Peru. On the other hand, in [14] conclude that there are differences between these species, the results of the present study shows that the other species found in Tacna is P. rugulosa Bitter.

Density and population structure

P. tarapacana presented higher density of trees (1420 indiv./Ha) in Cerro Purupuni, followed by Cerro Anatajave and Cerro Iscachancara and Huayllapujo and Camauta, and the lowest density was recorded in Condorpico and Quebrada Chillhuani and Quebrada Huañucucho with 400 indiv./ Ha (Table 1).

Regarding the population structure, the latizales surpasses $50 \%$ of the individuals in Huayllapujo and Camauta, Chiluyo Chico, Qda. Queñuta and Paucarani, being the highest percentage registered in Paucarani. The seedling record is much lower compared to latitudes and adult individuals. Of the 11 sectors evaluated, 4 forests present a record greater than $50 \%$ of adult individuals. The registry of adult individuals is higher in Cerro Juqhure (Kallapuma), representing $84 \%$ of the total registered individuals, being lower in Paucarani (11\%) (Table 1).

P. rugulosa showed higher density of trees $(2420$ indiv./Ha) in Cerro Timilla - Apacheta, followed by Yucamani Volcano and Huiltajavira Annex with 1880 indiv./Ha and 1720, respectively. The lowest density was registered in Queñoaplaza with 220 indiv./Ha and Cerro Paquercara with 389 indiv./Ha (Table 2).

Regarding the population structure, of the 13 sectors evaluated, none of the sectors exceeds $50 \%$ of latizales. Regarding samplings, two sectors surpass 50\% (Cerro Paquercara and Anexo Huiltajavira) and the evaluation in 8 sectors exceeds $50 \%$ of its composition by adult individuals. Cerro Paquercara is a forest in recovery since up to $11 \%$ of individuals of the total registered individuals were recorded (Table 2).

According to the registry, P. tarapacana presents young forests with greater presence of latizales (48\%), followed by adults with (45\%) and saplings with only (7\%). 
TABLE 1. DENSITY AND POPULATION STRUCTURE OF P. TARAPACANA FORESTS

\begin{tabular}{|c|c|c|c|c|c|c|c|c|c|c|}
\hline \multirow{3}{*}{$\begin{array}{c}\text { Province } \\
\text { Tarata }\end{array}$} & \multirow{3}{*}{$\begin{array}{l}\text { District } \\
\text { Ticaco }\end{array}$} & \multirow[t]{2}{*}{ Sector } & \multirow[t]{2}{*}{$\mathbf{N}^{0} *$} & \multirow[t]{2}{*}{ Density** } & \multicolumn{2}{|c|}{ Latizales } & \multicolumn{2}{|c|}{ Brinzales } & \multicolumn{2}{|c|}{ Adults } \\
\hline & & & & & \multicolumn{2}{|c|}{$\mathrm{N}^{\mathrm{o}}(\%)$} & \multicolumn{2}{|c|}{$\mathrm{N}^{\mathrm{o}}(\%)$} & \multicolumn{2}{|c|}{$\mathrm{N}^{\mathrm{o}}(\%)$} \\
\hline & & Cerro Purupuruni & 71 & 1420 & 23 & $(32)$ & 6 & $(7)$ & 42 & $(60)$ \\
\hline & Tarata & Cerro Juqhure (Kallapuma) & 37 & 740 & 5 & (14) & 1 & $(2)$ & 31 & (84) \\
\hline & & Cerro Antajave and Cerro Iscachancara & 70 & 1400 & 32 & $(46)$ & 5 & $(7)$ & 32 & (46) \\
\hline & & Huayllapujo y Camauta (near to Coracorani) & 70 & 1400 & 40 & $(58)$ & 9 & (13) & 20 & (29) \\
\hline & & Chiluyo chico & 48 & 960 & 27 & $(56)$ & 5 & (10) & 16 & (33) \\
\hline \multirow[t]{7}{*}{ Tacna } & Palca & Quebrada Queñuta & 45 & 900 & 33 & (73) & 0 & $(0)$ & 12 & (27) \\
\hline & & Paucarani & 29 & 580 & 25 & (89) & 0 & $(0)$ & 4 & (11) \\
\hline & & Condorpico & 20 & 400 & 6 & (30) & 0 & $(0)$ & 14 & (70) \\
\hline & & $\begin{array}{l}\text { Quebrada Chillhuani and Quebrada Huañu- } \\
\text { cucho }\end{array}$ & 20 & 400 & 9 & $(45)$ & 2 & (10) & 9 & (45) \\
\hline & & Cerro Curicurini and Quebrada Choroveco & 25 & 500 & 8 & $(32)$ & 4 & (12) & 15 & $(56)$ \\
\hline & & Cerro Pupusane and Quebrada Picanani & 49 & 980 & 24 & $(49)$ & 1 & $(2)$ & 24 & (49) \\
\hline & & TOTAL & 484 & -- & 232 & -- & 33 & -- & 218 & -- \\
\hline
\end{tabular}

TABLE 2. DENSITY AND POPULATION STRUCTURE OF P. RUGULOSA FORESTS

\begin{tabular}{|c|c|c|c|c|c|c|c|c|c|c|}
\hline \multirow{3}{*}{$\begin{array}{l}\text { Province } \\
\text { Tarata }\end{array}$} & \multirow{3}{*}{$\begin{array}{l}\text { District } \\
\text { Estique }\end{array}$} & \multirow[t]{2}{*}{ Sector } & \multirow{2}{*}{$\mathbf{N}^{0} *$} & \multirow{2}{*}{$\begin{array}{c}\text { Densi- } \\
\text { ty** }\end{array}$} & \multicolumn{2}{|c|}{ Latizales } & \multicolumn{2}{|c|}{ Brinzales } & \multicolumn{2}{|c|}{ Adults } \\
\hline & & & & & \multicolumn{2}{|c|}{$\mathrm{N}^{\mathrm{o}}(\%)$} & \multicolumn{2}{|c|}{$\mathrm{N}^{\mathrm{o}}(\%)$} & \multicolumn{2}{|c|}{$\mathrm{N}^{\mathrm{o}}(\%)$} \\
\hline & & Cerro Paquercara & 19 & 380 & 3 & (16) & 14 & (73) & 2 & (11) \\
\hline & Tarucachi & Quebrada Nuñamayane and Cerro Yaurimojo & 81 & 1620 & 20 & (25) & 2 & $(2)$ & 59 & (73) \\
\hline & Sitajara & Cerro Chuñave and Cerro Huarahuarani & 82 & 1640 & 32 & (40) & 23 & (28) & 27 & (32) \\
\hline & Ticaco & Cerro Chujovilque and Cerro Chajracape & 81 & 1620 & 17 & (21) & 3 & (3) & 61 & (75) \\
\hline & Tarata & Queñoaplaza & 11 & 220 & 2 & (18) & 2 & (18) & 7 & (64) \\
\hline & Susapaya & Cerro Taipesirca & 32 & 640 & 3 & (9) & 0 & $(0)$ & 29 & (91) \\
\hline & & Cerro Timilla - Apacheta & 121 & 2420 & 59 & (49) & 14 & (12) & 48 & (39) \\
\hline & & Cerro Tancan & 58 & 1160 & 8 & (14) & 16 & (29) & 34 & (57) \\
\hline & & Cerro Yocata & 24 & 480 & 4 & (17) & 8 & (33) & 12 & (50) \\
\hline $\begin{array}{l}\text { Jorge } \\
\text { Basadre }\end{array}$ & Ilabaya & Santa Cruz de Ilabaya & 52 & 1040 & 10 & (19) & 10 & (19) & 32 & (62) \\
\hline \multirow{5}{*}{$\begin{array}{l}\text { Candar- } \\
\text { ave }\end{array}$} & Camilaca & Cerro Pantara & 39 & 780 & 5 & (12) & 17 & (44) & 17 & (44) \\
\hline & Candarave & Anexo Huiltajavira & 86 & 1720 & 14 & (16) & 21 & (24) & 51 & (59) \\
\hline & & Volcan Yucamani & 94 & 1880 & 29 & (25) & 34 & (2) & 31 & (73) \\
\hline & & $\begin{array}{l}\text { Caserio Colpapampa and Quebrada Galluta (near } \\
\text { to Huiltajavira) }\end{array}$ & 47 & 940 & 10 & (40) & 11 & (28) & 26 & (32) \\
\hline & & TOTAL & 827 & -- & 216 & -- & 175 & -- & 436 & -- \\
\hline
\end{tabular}

In Quebrada Queñuta, Paucarani and Condorpico sectors, there are no seedlings showing signs that there is no recruitment of new individuals. P. rugulosa presents a higher percentage of adults $(51 \%)$, followed by latizales $(27 \%)$ and saplings $(22 \%)$. These forests are being altered and can be reduced in a short time because there would be no reproductive individuals.

Height and diameter of the trees

P. tarapacana has the highest altitude in Cerro Juqhure (Kallapuma) in Tarata, followed by Quebrada Chillhuani and Quebrada Huañucucho (Palca). The coefficient of variation shows less variability in Paucarani, Cerro Chiluyo Chico, Cerro Antajave and Cerro Iscachancara,
Condorpico, Cerro Curicurini and Quebrada Choroveco. The forest of the Juqhure hill (Kallapuma) has the highest average height $(1.68 \mathrm{~m})$, with the lowest record in Huayllapujo and Camauta with $0.83 \mathrm{~m}$ (Table 3).

P. rugulosa presents the highest average height in Caserio Colpapampa and Quebrada Galluta in the province of Candarave, followed by the sector of Cerro Taipesirca in the province of Tarata. The coefficient of variation shows less variability in Cerro Taipesirca (Tarata) and shows greater variability in Cerro Pantara of the province of Candarave. The forest of the hill Caserio Colpapampa and Quebrada Galluta has the highest average height $(1.62 \mathrm{~m})$, with the lowest record at Cerro Paquercara with $0.29 \mathrm{~m}$. In this forest, only two adult 
individuals were registered, with the highest proportion of saplings being recorded (Table 4).

Regarding the height of $P$. tarapacana, a great variability was observed within the plots sampled, varying individuals from $0.1 \mathrm{~m}$ the smallest tree in the district of Tarata in the sector Huayllapujo and Camauta and $3 \mathrm{~m}$ the largest in the district of Tarata, Juqhure sector. The results indicate that the variation depends on the presence of saplings (new individuals) and in others only of the latizales (juvenile individuals). In [15], they conclude that in forests of $P$. tarapacana trees have been found from one to seven meters high, contrary, [1] mentions that these forests do not exceed $2 \mathrm{~m}$ high. [13] reported that trees of P. tarapacana are trees between 5 and $10 \mathrm{~m}$. [16] mention that they are shrubs that measure from 1 to 4 meters high. The Regional Government of Tacna [12] concludes that in the high Andean zone of Tacna the trees of this species require 73 years to reach their biological maturity. The trees of P. tarapacana have an average of 80 years, being the longest of 137 years.

TABLE 3. HEIGHT OF P. TARAPACANA FORESTS

\begin{tabular}{|c|l|l|c|c|c|c|}
\hline Province & District & \multicolumn{1}{|c|}{ Sector } & Mínimum (m) & Máximum (m) & Average (m) & $\begin{array}{c}\text { Coefficient of } \\
\text { variation }\end{array}$ \\
\hline Tarata & Ticaco & Cerro Purupuruni & 0,15 & 2,50 & 1,22 & 0,46 \\
\cline { 2 - 7 } & Tarata & Cerro Juqhure (Kallapuma) & 0,30 & 3,80 & 1,68 & 0,40 \\
& & Cerro Antajave y Cerro Iscachancara & 0,20 & 2,20 & 1,15 & 0,53 \\
& & Huayllapujo y Camauta (cerca a Coracorani) & 0,10 & 1,90 & 0,83 & 0,51 \\
& & Chiluyo chico & 0,10 & 1,90 & 0,89 & 0,55 \\
\hline \multirow{2}{*}{ Tacna } & \multirow{2}{*}{ Palca } & Quebrada Queñuta & 0,40 & 1,70 & 0,91 & 0,37 \\
& & Paucarani & 0,33 & 1,27 & 0,68 & 0,33 \\
& & Condorpico & 0,31 & 2,30 & 1,21 & 0,52 \\
& & Quebrada Chillhuani y Quebrada Huanucucho & 0,30 & 2,60 & 1,24 & 0,51 \\
& & Cerro Curicurini y Quebrada Choroveco & 0,18 & 2,10 & 1,14 & 0,52 \\
\end{tabular}

TABLE 4. HEIGHT OF P. RUGULOSA FORESTS

\begin{tabular}{|c|c|c|c|c|c|c|}
\hline Province & District & Sector & Mínimum (m) & Máximum (m) & Average (m) & $\begin{array}{c}\text { Coefficient of } \\
\text { variation } \\
\end{array}$ \\
\hline \multirow[t]{9}{*}{ Tarata } & Estique & Cerro Paquercara & 0,10 & 0,80 & 0,29 & 0,68 \\
\hline & Tarucachi & Quebrada Nuñamayane y Cerro Yaurimojo & 0,00 & 2,50 & 1,25 & 0,43 \\
\hline & Sitajara & Cerro Chuñave y Cerro Huarahuarani & 0,12 & 3,40 & 0,95 & 0,85 \\
\hline & Ticaco & Cerro Chujovilque y Cerro Chajracape & 0,00 & 2,50 & 1,25 & 0,43 \\
\hline & Tarata & Queñoaplaza & 0,18 & 2,60 & 1,24 & 0,62 \\
\hline & \multirow[t]{4}{*}{ Susapaya } & Cerro Taipesirca & 0,53 & 3,10 & 1,61 & 0,31 \\
\hline & & Cerro Timilla - Apacheta & 0,15 & 3,60 & 1,01 & 0,53 \\
\hline & & Cerro Tancan & 0,10 & 3,10 & 1,36 & 0,73 \\
\hline & & Cerro Yocata & 0,12 & 2,60 & 1,14 & 0,74 \\
\hline Jorge Basadre & Ilabaya & Santa Cruz de Ilabaya & 0,15 & 2,50 & 1,18 & 0,54 \\
\hline \multirow[t]{4}{*}{ Candarave } & Camilaca & Cerro Pantara & 0,18 & 4,20 & 1,46 & 0,95 \\
\hline & \multirow[t]{3}{*}{ Candarave } & Anexo Huiltajavira & 0,10 & 4,00 & 1,30 & 0,70 \\
\hline & & Volcan Yucamani & 0,10 & 5,20 & 1,12 & 1,07 \\
\hline & & Caserio Colpapampa y Quebrada Galluta & 0,15 & 5,00 & 1,62 & 0,83 \\
\hline
\end{tabular}

P. rugulosa showed great variability within the evaluated plots since trees were registered from $0.1 \mathrm{~m}$ in the Estique district (Paquercara sector), Susapaya (Cerro Tancan sector), Candarave (Yucamani Volcan sector) and $5 \mathrm{~m}$, the greater height, in the district of Candarave, sector Caserio Colpapampa and Quebrada Galluta. [15] conclude that individuals of $P$. rugulosa measure between 3 and $5 \mathrm{~m}$ in height. Studies carried out by [17] [18] describe heights between 3 and 10m. [16] mention that it is a shrub that reaches heights between 2 and $5 \mathrm{~m}$. [19] reports averages of 1.10 to $2.43 \mathrm{~m}$ in height. The records of this study show that average heights would belong to secondary or recovery forests given the use and exploitation of these species as combustible material made by local people.

Regarding the diameter of the trees of queñoa (DAP), it is evident that the individuals of $P$. tarapacana with greater average were registered in Cerro Juqhure (Kallapuma), Cerro Antajave and Cerro Iscachancara, Chiluyo Chico, Quebrada Chillhuani and Quebrada Huañucucho with $0,10 \mathrm{~m}$; it is recorded according to the coefficient of variation that the results between zones are variable because in many cases within the plot the DAP $(0 \mathrm{~cm})$ was not measured, thus obtaining broad results, as shown in Table 5. In most of the evaluated sectors, the 
trees branch at a low altitude, and no data can be obtained at chest height (Table 5).

The highest averages of $P$. rugulosa were recorded in Quebrada Nuñamayane, Cerro Yaurimojo, Cerro Chujovilque and Cerro Chajracape with $0.08 \mathrm{~m}$. It is recorded according to the coefficient of variation that the results between zones are variable, in the areas of Cerro Taipesirca, Cerro Timilla-Apacheta, Queñoaplaza with $0.5 ; 0.5$ and 0.94 respectively, have less variability with respect to Cerro Chuñave and Cerro Huarahuarani, Santa Cruz de Ilabaya, Yucamani Volcano with 2.4; 2.0 and 2.0 respectively.
On the other hand, the highest rank was registered in Queñoaplaza and Cerro Chuñave and Cerro Huarahuarani (Tarata) with $0.50 \mathrm{~m}$ respectively; This is because in many cases, within the plot, the DAP $(0 \mathrm{~cm})$ was not measured, obtaining broad results as shown in Table 6 .

The DAP of queñoas is variable. In the study, it was not possible to register enough tall individuals since the measurement method implies a recording at a height of $1.5 \mathrm{~m}$. [12] recorded diameters between 0.4 and $0.6 \mathrm{~m}$ reaching this range in an approx. 40 years for $P$. tarapacana. In the case of $P$. rugulosa this range varies between 0.02 and $0.42 \mathrm{~m}$.

TABLE 5. DIAMETER OF THE TREES OF THE P. TARAPACANA FORESTS

\begin{tabular}{|c|c|c|c|c|c|c|}
\hline Province & District & Sector & $\begin{array}{c}\text { Mínimum } \\
\text { (m) }\end{array}$ & $\begin{array}{l}\text { Máximum } \\
\text { (m) }\end{array}$ & Average (m) & $\begin{array}{c}\text { Coefficient of } \\
\text { variation }\end{array}$ \\
\hline \multirow[t]{5}{*}{ Tarata } & Ticaco & Cerro Purupuruni & 0,30 & 0,00 & 0,30 & 0,03 \\
\hline & \multirow[t]{4}{*}{ Tarata } & Cerro Juqhure (Kallapuma) & 0,00 & 0,10 & 0,03 & 1,33 \\
\hline & & Cerro Antajave and Cerro Iscachancara & 0,00 & 0,10 & 0,02 & 2,00 \\
\hline & & Huayllapujo and Camauta (near to Coracorani) & 0,00 & 0,00 & 0,00 & 0 \\
\hline & & Chiluyo chico & 0,00 & 0,10 & 0,002 & 5,00 \\
\hline \multirow[t]{6}{*}{ Tacna } & \multirow[t]{6}{*}{ Palca } & Quebrada Queñuta & 0,00 & 0,00 & 0,00 & 0 \\
\hline & & Paucarani & 0,00 & 0,03 & 0,002 & 3,50 \\
\hline & & Condorpico & 0,00 & 0,05 & 0,007 & 1,42 \\
\hline & & Quebrada Chillhuani and Quebrada Huañucucho & 0,00 & 0,10 & 0,01 & 3,00 \\
\hline & & Cerro Curicurini and Quebrada Choroveco & 0,00 & 0,08 & 0,01 & 2,00 \\
\hline & & Cerro Pupusane and Quebrada Picanani & 0,00 & 0,03 & 0,002 & 4,00 \\
\hline
\end{tabular}

TABLE 6. DIAMETER OF THE TREES OF P. RUGULOSA FORESTS

\begin{tabular}{|c|c|c|c|c|c|c|}
\hline Province & District & Sector & $\begin{array}{l}\text { Mínimum } \\
\text { (m) }\end{array}$ & $\begin{array}{c}\text { Máximum } \\
\text { (m) }\end{array}$ & $\begin{array}{l}\text { Average } \\
\text { (m) }\end{array}$ & $\begin{array}{l}\text { Coefficient of } \\
\text { variation }\end{array}$ \\
\hline \multirow[t]{9}{*}{ Tarata } & Estique & Cerro Paquercara & 0,00 & 0,40 & 0,04 & 3,00 \\
\hline & Tarucachi & Quebrada Nuñamayane and Cerro Yaurimojo & 0,00 & 0,47 & 0,08 & 1,50 \\
\hline & Sitajara & Cerro Chuñave and Cerro Huarahuarani & 0,00 & 0,50 & 0,05 & 2,40 \\
\hline & Ticaco & Cerro Chujovilque and Cerro Chajracape & 0,00 & 0,47 & 0,08 & 1,50 \\
\hline & Tarata & Queñoaplaza & 0,00 & 0,50 & 0,17 & 0,94 \\
\hline & \multirow[t]{4}{*}{ Susapaya } & & 0,01 & 0,11 & 0,04 & 0,50 \\
\hline & & Cerro Timilla - Apacheta & 0,00 & 0,10 & 0,02 & 0,50 \\
\hline & & Cerro Tancan & 0,00 & 0,16 & 0,03 & 1,30 \\
\hline & & Cerro Yocata & 0,00 & 0,16 & 0,04 & 1,00 \\
\hline Jorge Basadre & Ilabaya & Santa Cruz de Ilabaya & 0,00 & 0,18 & 0,01 & 2,00 \\
\hline \multirow[t]{4}{*}{ Candarave } & Camilaca & Cerro Pantara & 0,00 & 0,16 & 0,03 & 1,30 \\
\hline & \multirow[t]{3}{*}{ Candarave } & Anexo Huiltajavira & 0,00 & 0,15 & 0,03 & 1,30 \\
\hline & & Volcan Yucamani & 0,00 & 0,21 & 0,02 & 2,00 \\
\hline & & Caserio Colpapampa y Quebrada Galluta & 0,00 & 0,34 & 0,05 & 1,40 \\
\hline
\end{tabular}

\section{Anthropogenic factors}

For both species, the results are similar. The anthropic factor for $P$. rugulosa is categorized as: Not Intervented with 660 individuals (76\%), Semi Intervening with 181 individuals (21\%) and Intervened with 29 individuals (3\%). For P. tarapacana it is categorized as: not intervened with 369 individuals (77\%), Semi Interventions with 102 individuals (21\%) and Intervened with 11 individuals $(2 \%)$.
The forests of $P$. tarapacana are in a good state of conservation, due to the fact that in the evaluation sectors the percentage was higher than $90 \%$ in most of the plots. In Cerro Antajave and Cerro Iscachancara, the percentage is $11 \%$ of individuals not intervened. The forests of $P$. rugulosa are in a regular state of conservation, records show that the majority of sectors are in the range of $50 \%$ to $75 \%$ of category not intervened. In the Semi-Intervened category, ranks between $10 \%$ and $38 \%$ are presented. 
Local people graze cattle (mainly cows) that feed on the saplings. During this action, mechanical damage is generated by the movement of animals and people. The soils are poor and adverse climatic conditions are known at these altitudes that affect the viability of the saplings.

In Tacna it has been observed that of the adult individuals they present some degree of anthropic or natural impact such as felling, burning, overgrazing, defoliation by the phenology, plague or disease. The main anthropic influences are due to the indiscriminate felling of trees, burning and livestock activity [1]; some use it to provide energy to the mines [6], and as a medicinal use, in our case there were clearings, burning, food for their livestock and especially the destruction of the new individuals as the roads of the settlers go through the middle of these forests [19]. Other studies indicate that certain seasons of the year burn these forests in order to fertilize the land [20], on the contrary in previously done studies it was evidenced that they cut and instead put another type of tree (eucalyptus, molle) [19]; being impacted not only the queñoas but the accompanying flora and fauna that in many cases are endemic to this type of forest and would not survive another ecosystem and would perish in time [21]. The opening of roads contributes to the fragmentation of habitat and the contamination with solid waste that besides polluting the soil distort the aesthetic harmony of the landscape. It can be considered that logging and grazing are the main activities that accelerate the degradation process of the forest and areas of influence [22].

Understanding the structure and composition of forests is the key to achieving an adequate management and restoration of these ecosystems. The forests of this area form very heterogeneous landscapes, with a high biological diversity, in which the alterations due to human activities have played a determining role. There is still limited information on what factors have shaped the structure and current composition of the forests, and how the species found respond to environmental stress, particularly in their early stages of development, which can be the key to understanding their dynamics and response to changes environmental.

One of the fundamental bases of the sustainable management of the forests is the maintenance of the natural regeneration. This form of management requires that species regenerate naturally to maintain their populations and ensure the future productivity of the forest [23] - [24].

\section{CONCLUSIONS AND RECOMMENDATIONS}

On basis of the data gathered, we established next conclusions:

- Two species of queñoa are distributed in Tacna: $P$. tarapacana and P. rugulosa.

- P. tarapacana had a lower density than P. rugulosa.

- The height of queñoas is variable. The forests of queñoa showed are forests in process of natural restoration.

- The diameter at breast height showed that trees of queñoa are younger and small. It means that forests are growing or initiating a resilience process.

- The main human activities affect the population structure of queñoa forests are: grazing, burning, provide energy to mines, reforestation (with other species) and opening of roads.

Our recommendation about a conservation plan for queñoa forests are:

1. Education: to design a programme about alternative education with intercultural focus (local governments), to improve environmental education programme (Ministry of Education and local units), and to incorporate a special chapter about the importance of queñoa forests in formal education (Ministry of Education).

2. Communication and empowerment of local populations: to design accessible ways for communication through focus groups, to create a network of social communicators (bilingual), to design a programme about environmental citizen, to publish research about the importance (both social and economic values) of queñoa forests for population (rural and urban) including ecosystem services.

3. Conservation and sustainable management: to develop biological inventories about diversity associated, to identify priority areas for restoration and conservation, to promote use of sustainable energy, to design a programme of ecotourism (communitarian rural tourism) for improving incoming of villagers, and to implement a programme of agroforestry.

4. Policies and regulations: to establish regulations of national, regional and local about the protection of queñoa forests, to promote protection of forests by companies through to subsides, incentives or social responsibility mechanisms.

5. Research and monitoring: to map the priority areas to conservation; to assess the economic value of biological resources associated; to study the phenology, taxonomy, and biomass of queñoas; to study the effects of climatic change about queñoa forests; to compilate the traditional knowledge of villagers; and, to realize research about social importance of those high Andean forests.

\section{ACKNOWLEDGMENTS}

Juan Pablo Franco León provided advice during the collection, data analysis and drafting of the manuscript. Alfredo Tupayachi Herrera (Herbario Vargas - CUZ) provided taxonomic information and complemented the research work. Alejandro Murillo Calisaya and Avelino García Lévano accompanied and supported the activities of information gathering in the field. 


\section{REFERENCES}

[1] M. Kessler. Bosque de Polylepis. Botánica Económica de Los Andes Centrales. In: Baslev M, ed. La Paz, Universidad Mayor de San Andrés, pp. 110-120, 2006. http://beisa.dk/Publications/ BEISA \%20Book\%20pdfer/Capitulo\%2007.pdf

[2] Renison D., E. Cuyckens, S. Pacheco, G.S. Guzmán, H.R. Grau, P. Marcora, and G. Robledo. Distribución y estado de conservación de las poblaciones de árboles y arbustos del género Polylepis (Rosaceae) en las montañas de Argentina. Ecología Austral 23: 27-36, 2013. https://doi.org/10.25260/ EA.18.28.1.1.522

[3] Mendoza, W., \& Cano, A. Diversidad del género Polylepis (Rosaceae, Sanguisorbeae) en los Andes peruanos. Revista Peruana De Biología, Vol 18, No 2: 197 - 200, 2011. https://doi. org/10.15381/rpb.v18i2.228

[4] Mendoza, W. and B. León. Rosaceae endémica del Perú, Rev. Per. Biol., 3 (2): 583-585, 2006. http://revistasinvestigacion. unmsm.edu.pe/index.php/rpb/article/view/1909/1678

[5] Mendoza, W. and A. Cano. El género Polylepis en el Perú. Editorial Académica Española, Lima, Perú. 2012.

[6] Collahuasi. Queñoa: árbol de las alturas. 1ra edición. Gerencia de Medio Ambiente Compañía Minera Doña Inés de Collahuasi SCM Jack Stern y Cía. Ltda., 2011.

[7] Zutta, B. R.; Rundel, P. W.; Soto, A.; Saatchi, S.; Velazco, Y.; Casana, J. D.; Gauthier, P.; W. Buermann. Prediciendo la distribución de Polylepis: bosques andinos vulnerables y cada vez más importantes. Revista Peruana de Biología, Agosto: 205212, 2012. DOI: https://doi.org/10.15381/rpb.v19i2.849

[8] MINAGRI - Ministerio de Agricultura. Instituto Nacional de Recursos Naturales. Monitoreo de la Biodiversidad. Lima, Perú. 2004.

[9] Gutiérrez-Salazar, A. and A. García-Mendoza. Propuesta de una técnica para herborizar plantas de la familia Crassulaceae. Boletín de la Sociedad Botánica de México, 65: 107-110, 2000. DOI: https://10.17129/botsci.1601

[10] Parrales, M. Diversidad y distribución altitudinal de orquídeas terrestres del cerro Uyuca. Honduras, 2015.

[11] MINAM - Ministerio del Ambiente. 2015. Guía de inventario de la flora y vegetación. Lima - Perú.

[12] GORE Tacna - Gobierno Regional de Tacna. Diagnóstico de Diversidad Biológica en la Región Tacna, 2016.

[13] Kessler, M. and A. N. Schmidt - Lebuhn. Taxonomical and distributional notes on Polylepis (Rosaceae). Org. Divers. Evol. 6, Electr. Suppl. 1:1-10, 2006. https://www.senckenberg.de/ odes/06-01.pdf
[14] Schmidt-Lebuhn A.N., M. Kessler and M. Kumar. Promiscuity in the Andes: species relationships in Polylepis (Rosaceae, Sanguisorbeae) based on AFLP and morphology. Systematic Botany, 31(3), 2006: pp. 547-559. https://www.jstor.org/stable $/ 25064184$

[15] Muñoz, S. and V. Serra. Documento de trabajo. Estado de conservación de las plantas de Chile. CONAMA, Comisión Nacional del Medio Ambiente. Chile. 2006. 7p.

[16] Mendoza, W. and A. Cano. Estudio preliminar de la Familia Rosaceae del Perú. Boletín Informativo Kallpay. Facultad de Ingeniería Agraria. Universidad Católica Sedes Sapientiae, 2015. pp 14-16. http://www.ucss.edu.pe/images/fia/boletin/kallpay 01/ kallpay $\% 2014-16 \% 20-\% 20$ Notas $\% 20$ cient $\%$ C $3 \%$ ADficas $\% 20$ -\%20Estudio\%20familia\%20Rosaceae $\% 20$ Per $\%$ C3\%BA.pdf

[17] Fjeldså J. and N. Krabbe.. Birds of the high Andes. Zoological Museum, University of Copenhagen and Apollo Books, Copenhagen. 1990.

[18] Fjeldså, J. and M. Kessler. Conserving the biological diversity of Polylepis Woodlands of the Highland of Peru and Bolivia. A contribution to sustainable natural resource management in the Andes. NORDECO, Copenhagen. 1996, 250 p.

[19] Morales, L. Estado Actual del bosque de Polylepis y su Eficiencia en la Captura de $\mathrm{CO} 2$ en la Provincia Tarata, Departamento de Tacna. 2014. Universidad Nacional Jorge Basadre Grohman. http://repositorio.unjbg.edu.pe/bitstream/handle/UNJBG/641/ TM0090.pdf? sequence $=1$ \&isAllowed $=y$

[20] Yallico, E. Distribución de Polylepis en el Sur de Puno, Proyecto Árbol Andino, Puno - Perú. 1992.

[21] Kessler, M. and P. Dreisch. Causas e historia de la destrucción de bosques altoandinos en Bolivia. Ecología en Bolivia, 1993, 21: 1-18. http://ecologiaenbolivia.com/documents/KesslerDriesch21.pdf

[22] Chancayauri, C. Determinación de la representatividad biológica de la flora asociada al bosque de Polylepis rugulosa Bitter "queñoa" del Centro Poblado menor de Muylaque - Moquegua, 2005-2006, Moquegua, Perú, 2008.

[23] Bawa, K. and R. Seidler. Natural forest management and conservation of biodiversity in tropical forests. Conservation Biology, 1998, 12: 46-55. https://www.jstor.org/stable/2387461

[24] Mostacedo, B.and T. S. Fredericksen. Regeneration status of important forest tree species in Bolivia: assessment and recommendations. Forest Ecology and Management, 1999, 124: 263-273. DOI: https://10.1016/S0378-1127(99)00076-6 